\title{
Ten year follow up of farmers with farmer's lung
}

\author{
O D CUTHBERT AND M F GORDON
}

From Evie, Orkney, UK

\begin{abstract}
Twenty-nine patients previously diagnosed as having suffered from farmer's lung in or before 1970 were asked whether the condition had recurred and what measures they had taken to avoid such recurrence. Those who had retired from farming had been least affected by recurrence, while those who continued to farm had been protected by making silage instead of hay or by wearing protective respirators. To be effective, a respirator should be worn on every occasion that farm dust is encountered and must be properly maintained.
\end{abstract}

The best treatment for allergic disease is to remove the patient from contact with the offending allergen. In farmer's lung this ideal is not easily attainable. To study the effectiveness of this advice and other measures available to farmers who have suffered from this condition, we have followed up a group who were diagnosed as having had farmer's lung 10 or more years ago. In 1970 a team of investigators from Edinburgh and Dundee conducted a pilot study into the prevalence of farmer's lung in Scotland. ${ }^{1}$ Among the areas studied were two of the islands of Orkney-Stronsay and Sanday. They found 31 farmers and farmworkers who had had recent symptoms of farmer's lung-17 on Stronsay and 14 on Sanday-a rate of 86 per thousand of the working population.

Now, after 10 years, we have reassessed the condition of as many of these subjects as were still available, together with six other patients from the mainland of Orkney known to have had farmer's lung at about the same period. In all, 29 patients were studied. The investigation set out to establish whether any of the patients had suffered a recurrence of the condition; their present state of health, especially in regard to respiratory conditions; whether they had retired from farming, and when; and to what extent they had changed their farming methods.

\section{Materials and methods}

Of the 31 patients identified during the 1970 survey on the islands of Stronsay and Sanday, two had died, both from myocardial infarction, four were not

Received 29 April 1982

Accepted 15 July 1982 traced, and two declined to take part; the remaining 23 , together with the six mainland patients, were invited to attend at their local surgery, the consent and cooperation of their own family doctors having first been obtained.

All subjects completed questionnaires about their present occupation or retirement, alterations in their method of work (by making silage instead of hay, by wearing respirators, by using antifugal agents, etc), and their state of health during the past 10 years, with special emphasis on respiratory symptoms while working with hay or grain (there will always be some moulding of harvested feedstuffs in Orkney, where the climate is damp). Forced expiratory volume $\left(\mathrm{FEV}_{1}\right)$ and forced vital capacity (FVC) were measured for each subject, at rest and away from their working environment.

Samples of blood were taken and the serum was sent for radioimmune assay of antibodies to Micropolyspora faeni.

Skin prick tests were performed, using extracts of cat fur, horse dander, mixed grass pollens, house dust mite (Dermatophagoides pteronyssinus), three species of storage mites (Tyrophagus longior, Acarus farris, and Glycyphagus destructor), Aspergillus fumigatus, and $M$ faeni.

Because of the difficulties of conveying patients from the islands, chest radiographs were taken only when there were definite indications of disease.

\section{Results}

\section{QUESTIONNAIRES}

Answers to the questionnaires suggested, firstly, that of the 29 subjects interviewed, two suffered from asthma only and had probably never had farmer's lung (such a doubt had also been expressed about them at the time of the earlier survey). The remain- 
ing 27 could be divided into three groups: (1) those who had had further attacks of farmer's lung or in whom the condition had become chronic, (2) those in whom recurrence was doubtful, and (3) those who had had no more trouble from the condition.

Group 1-Eight patients (30\%) had had further trouble (table 1a). Of the four who had had further acute attacks in the early years of the decade, one had retired in $\mathbf{1 9 7 5}$ and had had no further trouble and the others had taken to wearing respirators at least part of the time when working. In two the condition had become "chronic" and though not apparently causing them much distress, they both had high titres of antibody to $M$ faeni, despite wearing respirators intermittently. The last two had had recent acute attacks with high antibody titres and radiological evidence of disease. One had continued to farm wearing a respirator only occasionally while the other had given up farming except for looking after the chickens.

Group 2-Of the four doubtful recurrences (table 1b), one had had a single attack when turning over some mouldy oats-his antibody titre is now within normal limits; one had developed chronic bronchitis but still had a raised antibody titre and might also have chronic farmer's lung masked by bronchitis, and the third also had symptoms that might be accounted for by chronic disease with a raised antibody titre. The fourth had given up full time farming in 1970 and since then had regularly worn an oronasal ("half-mask") type respirator when he did work; he suffered occasional "malaise" a few hours after handling mouldy hay but no other relevant symptoms. Nevertheless, his antibody titre remained high.

Group 3-The remaining 15 patients (table 1c) had remained clear of recurrence. Ten had retired completely from farming during the decade, six of them before 1972. Of the other five, three had gone over to making silage only instead of hay and the other two wore respirators whenever they worked, although one had only recently started doing so.

Table 1 Changes in farming practice

\begin{tabular}{lllllll}
\hline Subject & First attack & Recurrence & Year retired & Started & Started \\
No & of & during & from & Started \\
farmer's lung & $1970-80$ & farming & silage & $\begin{array}{l}\text { Antibody to } \\
\text { respirator faeni }\end{array}$ & antifungal \\
\hline
\end{tabular}

\begin{tabular}{|c|c|c|c|c|c|c|c|}
\hline \multirow[b]{2}{*}{$\begin{array}{l}1 \\
2 \\
3 \\
4 \\
5 \\
6 \\
7 \\
8\end{array}$} & \multicolumn{7}{|c|}{ (a) Farmers who have suffered a recurrence of farmer's lung during $1970-80$} \\
\hline & $\begin{array}{l}1969-70 \\
1969-70 \\
\text { Before } 1970 \\
1964 \\
1970 \\
1970-1 \\
1970 \\
1970-1\end{array}$ & $\begin{array}{l}\text { Chronic } \\
1971 \\
1973-5 \\
\text { Chronic } \\
1977 \text { \& } 79 \\
1975 \\
1980 \\
1972\end{array}$ & $\begin{array}{l}1978 \\
1975 \\
- \\
(1978)^{*} \\
(1972) \\
1971)\end{array}$ & $\begin{array}{l}- \\
\overline{(1975) \dagger} \\
\frac{(1975)}{-}\end{array}$ & $\begin{array}{l}\text { D } 1970 \\
\text { HM } 1971 \\
\overline{\text { (D \& HM) }} \\
\text { D } 1970, \text { HM } 1978 \\
\text { (HM 1977) } \\
\overline{(H M)}\end{array}$ & $\begin{array}{l}\overline{1977} \\
1971-2 \\
- \\
\frac{1975}{-} \\
-\end{array}$ & $\begin{array}{r}516 \\
207 \\
74 \\
679 \\
463 \\
17 \\
250 \\
4\end{array}$ \\
\hline \multicolumn{8}{|c|}{ (b) Farmers who may possibly have had recurrence of farmer's lung during $1970-80$} \\
\hline $\begin{array}{r}9 \\
10 \\
11 \\
12\end{array}$ & $\begin{array}{l}1967 \\
1969-70 \\
1965-70 \\
1968 ; 1969-70\end{array}$ & $\begin{array}{l}1975 \\
\text { ? Chronic } \\
\text { ? Chronic } \\
-\end{array}$ & $\begin{array}{l}\overline{(1970)} \\
1970) \\
1970)\end{array}$ & $\begin{array}{l}(1970) \\
- \\
-\end{array}$ & $\begin{array}{l}-\overline{(D)} \\
(D 1970) \\
\text { HM } 1970\end{array}$ & $\overline{-}$ & $\begin{array}{r}16 \\
312 \\
134 \\
532\end{array}$ \\
\hline \multicolumn{8}{|c|}{ (c) Farmers who have had no recurrence of symptoms of farmer's lung 1970-80 } \\
\hline $\begin{array}{l}13 \\
14 \\
15 \\
16 \\
17 \\
18 \\
19 \\
20 \\
21 \\
22 \\
23 \\
24 \\
25 \\
26 \\
27\end{array}$ & $\begin{array}{l}1938-62 \\
1969-70 \\
1967 \\
\text { Before } 1970 \\
1968-9 ; 1969-70 \\
1968-9 \\
1968-9 \\
1968-9 \\
1966 \\
1969-70 \\
1968-9 ; 1969-70 \\
1968-9 ; 1969-70 \\
1969 \\
1969 \\
1967\end{array}$ & & $\begin{array}{l}1964 \\
1977 \\
1972 \\
1972 \\
1977 \\
\overline{1} \\
\frac{1}{1970} \\
1976 \\
\frac{1}{1955)} \\
-\end{array}$ & $\begin{array}{l}- \\
\overline{(1970)} \\
\frac{1}{1971} \\
\overline{1970} \\
(1973) \\
\overline{(1971)} \\
- \\
1967\end{array}$ & $\begin{array}{l}- \\
(\mathrm{D}) \\
\text { HM 1970) } \\
- \\
- \\
\overline{(1975)} \\
\text { HM } 1970 \\
\text { 1979 } \\
\text { HM } 1979 \\
\text { HM } 1969 \\
-\end{array}$ & $\begin{array}{l}- \\
- \\
\overline{1} \\
\overline{1973} \\
1974 \\
1973 \\
- \\
- \\
-\end{array}$ & $\begin{array}{r}329 \\
96 \\
371 \\
23 \\
122 \\
42 \\
40 \\
135 \\
14 \\
64 \\
78 \\
138 \\
121 \\
58 \\
47\end{array}$ \\
\hline
\end{tabular}

*In parentheses only partial retirement.

†In parentheses silage made as well as hay.

$¥$ In parentheses respirators worn only occasionally.

$\S$ Normal range $60 \mathrm{ru}$.

$\mathrm{D}=$ Disposable tube. HM = Oronasal (half-mask) type. 


\section{ANTIBODIES TO M FAENI}

Radioimmune assay showed antibody titres to $M$ faeni above normal values (60 ru) in all but eight of the subjects. Two of the eight had had definite recurrences, both having been shown to have antibodies in their sera by gel diffusion at the time of their attacks. Many of those who had retired from active farming still had high antibody titres including one who retired in 1964.

\section{OTHER RESPIRATORY CONDITIONS AND SKIN} TEST RESULTS (table 2)

Five of the 27 subjects (18.5\%) gave a history of asthma associated with farm dust, of whom four were skin test positive to one or more of the storage

Table 2 Farmers who have had other respiratory disease as well as farmer's lung and skin test results to storage mites and to other common farm allergens

\begin{tabular}{llll}
\hline $\begin{array}{l}\text { Subject } \\
\text { No }\end{array}$ & Respiratory condition & \multicolumn{2}{l}{ Skin test result } \\
\cline { 3 - 4 } & & Mites & Multiple \\
\hline 1 & Asthma & + & - \\
8 & Asthma and rhinitis & + & - \\
9 & Rhinitis & - & - \\
10 & Chronic bronchitis & - & - \\
14 & Astham & - & - \\
17 & Rhinitis & - & - \\
22 & Asthma and rhinitis & - & - \\
23 & Asthma and rhinitis & + & - \\
24 & Chronic bronchitis & - & - \\
$28^{*}$ & Asthma & + & + \\
$29^{*}$ & Asthma & - & - \\
\hline
\end{tabular}

*Probably never suffered from farmer's lung.

mites but to no other allergen. Three others were also positive to these mites but without immediate type symptoms of allergic disease.

In addition, one of the two farmers thought to have asthma rather than farmer's lung was atopic, with multiple positive skin tests.

As noted above, two of the farmers had developed chronic bronchitis.

\section{LUNG FUNCTION TESTS}

Lung function tests supported the diagnosis in four of the asthmatic and in one of the bronchitic subjects. In only two of those who had had recurrences of farmer's lung in the past 10 years did the lung function tests give results consistent with restrictive airways disease. These were the two who had had recent acute recurrences with raised antibody titres and radiological evidence of disease.

\section{Discussion}

Farmer's lung can be a difficult diagnosis to make, especially by retrospective questioning, except when presenting as an acute condition with classical symptoms four to eight hours after the handling of mouldy hay or grain. Those who have suffered previously can recognise the symptoms, and the presence of raised antibody titres in the sera is of real if limited help. As earlier authors have pointed out, the condition may become chronic or have an insidious onset, while many farmers may develop antibodies to the thermophyllic actinomyces without ever suffering from the disease. ${ }^{2}$ The observation that over half of those who have given up active farming continue to show high levels of antibody, however, suggests that remaining in the farming environment may allow sufficient contact with these antigens to top up their antibody pool without precipitating an attack.

It seems that retiring completely from active farming and leaving the farming environment is the best safeguard against recurring attacks.

After reviewing the rest of the patients, we formed the opinion that those who continue to farm, either full time or part time, can obtain protection by using a respirator (see appendix), abandoning the use of hay as a foodstuff, and using the grass crop to make silage for winter feed. It is doubtful whether in either instance half measures are of any use. To be effective, respirators must be worn on every occasion that farm dust, especially in an enclosed environment, is likely to be encountered. They should, however, be regarded as adjuncts to, not substitutes for, measures to control dust, such as the careful handling of hay bales and the maintenance of storage barns. To be worth while, silage must be made to the complete exclusion of hay-and be made properly. The alternative, of drying hay adequately after harvest, might be satisfactory but is not at present a viable method in Orkney.

When properly used antifungal agents are effective in protecting grain from moulding but have not so far proved very satisfactory for hay, especially when baled wet (I G Jeffrey, personal communication).

Finally, it is worth noting that four out of the 29 subjects $(14 \%)$ suffered from asthma due to farm dust, were skin test positive to one or more of the storage mites, and could therefore be said to be suffering from "barn allergy." 3 Exactly the same precautions are indicated for this condition as for farmer's lung. Since it is better in both conditions to take preventive measures before sensitisation occurs, all farmers would be well advised to make regular and proper use of a respirator of approved 
design, especially when working in confined spaces, whatever other farming methods they may use.

We thank Dr Ian Grant for his help in providing details of the patients seen in the 1970 survey; $\mathrm{Dr}$ Gavin Boyd for the serological tests; Dr David Hunter of Stronsay and the late Dr Catherine Stockton of Sanday for their cooperation and for allowing us to see their patients; Mr R Drennan Watson, of the North of Scotland College of Agriculture, for advice on respirators; the Orkney Health Board for financial assistance; and, finally, the patients themselves for their ready cooperation.

\section{Appendix}

Respirators suitable for use by farmworkers working with hay, grain, etc as a protection against the inhalation of dust particles.

Disposable filtering face-piece respirators

Description: A cup of efficient filtering material held on head by two straps, with malleable metal strip to be moulded around nose.

Advantages: Low breathing resistance. Comfortable to wear for fairly long periods. Readily replaceable.

Disadvantages: Need constant replacing and therefore fairly expensive.

Oronasal (half face-piece) respirators (BS 2091)

Description: Rubber face-piece covering mouth and nose and held on head by straps. One or more disposable dust cartridge filters.

Advantages: Filters require changing at relatively infrequent intervals and therefore after initial outlay are less expensive than disposable respirators.

Disadvantages: Uncomfortable to wear for more than 10-15 minutes, especially when working strenuously. High breathing resistance. Require careful fitting to obtain airtight fit around face.

\section{Powered respirator helmets}

Description:

Plastic helmet with electric motor built into helmet, with transparent plastic moveable visor. The motor is run off a small portable powerpack and drives air through a filter.

Advantages: Light and comfortable to wear and eliminate problems of sweat around face (prevalent with oronasal respirator). Has added advantage of crash helmet protection.

Disadvantages: Some restriction of hearing. Costly.

It is important to emphasise that all three of these respirator types afford protection against dust particles but offer no protection against vapours or gasses from chemical sprays etc.

Full details about these and other types of respirators and indications for their use may be found in the North of Scotland College of Agriculture Bulletin No 18 (October 1979)-“Dangerous dusts and vapours in agriculture-choosing and using a respirator"-obtainable from the librarian of the college at 581 Kings Street, Aberdeen.

\section{References}

' Grant IWB, Blyth W, Wardrop VE, Gordon RM, Pearson JCG, Mair A. Prevalence of farmer's lung in Scotland: a pilot survey. Br Med J 1972;i:530-4.

${ }^{2}$ Pepys J, Jenkins PA. Precipitin (FLH) test in farmer's lung. Thorax 1965;20:21-35.

${ }^{3}$ Cuthbert OD, Brostoff J, Wraith DG, Brighton WD. "Barn allergy": asthma and rhinitis due to storage mites. Clin Allergy 1979;4:229-36. 